Nova Southeastern University

Florida

NOVA SOUTHEASTERN

UNIVERSITY

NSUWorks

Marine \& Environmental Sciences Faculty Articles Department of Marine and Environmental Sciences

$1-1-2015$

\title{
Growth, Injury, and Population Dynamics in the Extant Cyrtocrinid Holopus mikihe (Crinoidea, Echinodermata) near Roatan, Honduras
}

\section{V.J. Syverson}

University of Michigan - Ann Arbor

Charles G. Messing

Nova Southeastern University, messingc@nova.edu

Karl Stanley

Roatan Institute of Deepsea Exploration - Honduras

Tomasz K. Baumiller

University of Michigan - Ann Arbor

Find out more information about Nova Southeastern University and the Halmos College of Natural Sciences and Oceanography.

Follow this and additional works at: https://nsuworks.nova.edu/occ_facarticles

Part of the Marine Biology Commons, and the Oceanography and Atmospheric Sciences and Meteorology Commons

\section{NSUWorks Citation}

V. J. Syverson, Charles G. Messing, Karl Stanley, and Tomasz K. Baumiller. 2015. Growth, Injury, and Population Dynamics in the Extant Cyrtocrinid Holopus mikihe (Crinoidea, Echinodermata) near Roatan, Honduras .Bulletin of Marine Science , (1) : 47 -61. https://nsuworks.nova.edu/occ_facarticles/489.

This Article is brought to you for free and open access by the Department of Marine and Environmental Sciences at NSUWorks. It has been accepted for inclusion in Marine \& Environmental Sciences Faculty Articles by an authorized administrator of NSUWorks. For more information, please contact nsuworks@nova.edu. 


\section{Growth, injury, and population dynamics in the extant cyrtocrinid Holopus mikihe (Crinoidea, Echinodermata) near Roatán, Honduras}

\author{
${ }^{1}$ University of Michigan Museum \\ of Paleontology, 1109 Geddes \\ Avenue, Ann Arbor, Michigan \\ 48109. \\ ${ }^{2}$ Nova Southeastern University \\ Oceanographic Center, 8000 \\ North Ocean Drive, Dania Beach, \\ Florida 33004. \\ ${ }^{3}$ Roatán Institute of Deepsea \\ Exploration, Half Moon Bay, \\ Roatán, Honduras. \\ ${ }^{*}$ Corresponding author email: \\ <vjsyvers@umich.edu>.
}

Date Submitted: 9 September, 2014 Date Accepted: 3 November, 2014. Available Online: 5 December, 2014.

\author{
VJ Syverson ${ }^{1 *}$ \\ Charles G Messing ${ }^{2}$ \\ Karl Stanley ${ }^{3}$ \\ Tomasz K Baumiller ${ }^{1}$
}

\begin{abstract}
The crinoid order Cyrtocrinida is known mainly from Mesozoic fossils; its few surviving members, all from bathyal environments, are among the most peculiar living crinoids. Cyrtocrinids attributed to Holopus mikihe Donovan and Pawson, 2008, have been observed in large numbers via submersible off the western coast of Roatán, Honduras, on vertical and overhanging walls at depths between 430 and $640 \mathrm{~m}$. Observations in 2012, 2013, and 2014 have permitted the first estimates of population structure, growth, and regeneration. Two size modes were observed; the flat barnacle-like "juvenile" stage resembles confamilial and co-occurring Cyathidium pourtalesi Améziane, 1999, whereas the larger "adults" elevate the crown on a stumplike calyx. The 99th percentile growth rate was $0.19 \mathrm{~cm} \mathrm{yr}^{-1}$, giving a minimum predicted age of 16 yrs for the largest specimen and $8.7 \mathrm{yrs}$ for the median specimen; the median growth rate was $0.04 \mathrm{~cm} \mathrm{yr}^{-1}$, corresponding to 72 and $39 \mathrm{yrs}$. However, the slower rate of growth in juvenile compared to adult specimens means that these ages are underestimates; actual median age may be closer to $50 \mathrm{yrs}$. Arm regeneration rate is estimated at $0.6 \mathrm{~cm} \mathrm{yr}^{-1}$, and $9.8 \%$ of adult individuals were visibly injured, giving an interval of about $1.4 \mathrm{yrs}$ between arm loss events. No recruitment or mortality was observed, and aggregations of evenly-sized individuals were prevalent, consistent with sporadic local recruitment and mortality.
\end{abstract}

Cyrtocrinids are a highly-derived order of sessile articulate crinoids characterized by cementation to a hard substrate, with the column either short or entirely absent (Hess et al. 2011). Although the origins of the group are obscure, they are thought to be monophyletic based on both morphological and molecular evidence, and to have diverged from their closest relatives, the hyocrinids, about $187 \mathrm{Ma}$ (Rouse et al. 2013). Cyrtocrinids originated in the Triassic (Salamon et al. 2009), radiated during the Middle Jurassic, and remained highly diverse and successful into the Early Cretaceous, with 15 families and numerous species (Hess et al. 2011), and habitats ranging from shallow (Baumiller and Gaździcki 1996, Donovan and Jakobsen 2004) to deep (Charbonnier et al. 2007, Wisshak et al. 2009) water. Figure 1 shows the generic 


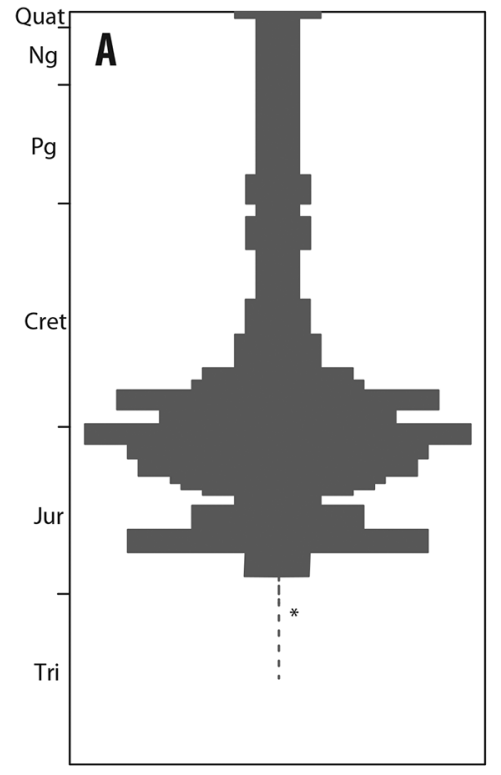

All Cyrtocrinida

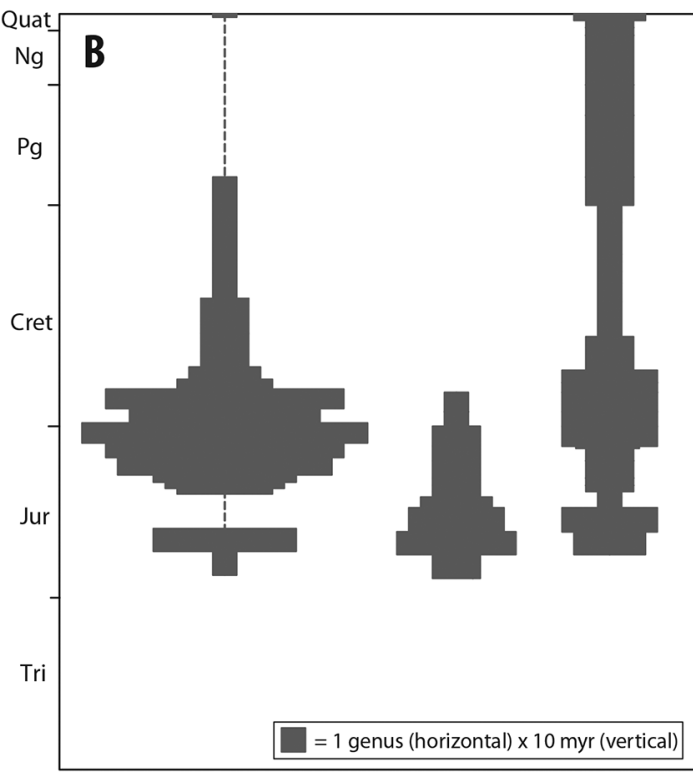

Eugeniacrinitoidea

Plicatocrinoidea Holopodina

Figure 1. Spindle diagram of cyrtocrinid generic diversity through time: (A) all cyrtocrinids, (B) all cyrtocrinids by superfamily. Vertical distance is proportional to time, with the height of the Holocene exaggerated by a factor of two for visibility; horizontal distance indicates generic diversity of the cyrtocrinids during each geologic stage. Extension into the Triassic, indicated by asterisk in (A), is based on ossicles of cyrtocrinid affinity reported from the Rhaetian (Salamon et al. 2009) and undescribed specimens from the Carnian reportedly resembling cyrtocrinids (Hess 2006, Salamon et al. 2009). These Triassic specimens have not been identified to the superfamily level and are therefore not included in (B).

diversity of the order (A) and its three constituent superfamilies (B). Cyrtocrinids covered the gradient of habitat depth either until the end of the Mesozoic or well into the Paleogene, depending on paleoenvironment reconstruction (Donovan and Jakobsen 2004, Wisshak et al. 2009). If the former, they may have been driven out of shallow environments by further increases in predatory pressure from the Paleogene teleost radiation (Bottjer and Jablonski 1988, Vermeij 1993), possibly in combination with the end-Cretaceous extinction. If the latter, some may have remained in protected shallow-water relict communities. In either case, as a result of the poor fossilization potential of deep-water habitats, the fossil record of the cyrtocrinids is entirely unknown between the Miocene and the Recent.

Only three cyrtocrinid families are known to have survived beyond the Mesozoic. Four extant genera have been found, all living in deep water. Of these, Neogymnocrinus and Proeudesicrinus are known only from New Caledonia (Améziane-Cominardi et al. 1990); each is the sole post-Mesozoic representative of its family (Sclerocrinidae and Eudesicrinidae, respectively) (Hess et al. 2011). The two genera constituting Holopodidae are more widely distributed across the fossil record, as well as the modern ocean: living Holopus has been found in the Caribbean Sea, as well as in New Caledonia, and Cyathidium in the Caribbean Sea, the Azores, and the Comoros (Améziane-Cominardi 1999), and both are known from Jurassic through Miocene strata of Europe.

Holopodidae are characterized by the lack of a column, cementation of the calyx directly onto a hard substrate, and the ability to coil the arms tightly. The skeletal 
Table 1. Age estimates for extant stalked crinoids.

\begin{tabular}{lcccl}
\hline Taxon & Depth $(\mathrm{m})$ & Mean age (yrs) & Max age (yrs) & Reference \\
\hline Metacrinus rotundus & $100-200$ & 10 & & Oji 1989 \\
Cenocrinus asterius & 215 & & $>20$ & Messing et al. 2007 \\
Endoxocrinus wyvillethompsoni & $1,420-2,615$ & 15 & $>20$ & Roux 1976 \\
Bathycrinus carpenteri & $1,420-2,615$ & & $10-15$ & Duco and Roux 1981 \\
Holopus mikihe & $430-640$ & 39 & 73 & Present study \\
\hline
\end{tabular}

and soft-tissue anatomy and histology of modern Holopus and Cyathidium have been described in great detail from collected specimens (Carpenter 1884, Grimmer and Holland 1990, Donovan 1992, Heinzeller and Fechter 1995, Améziane-Cominardi 1999). Donovan and Pawson (2008) comment on the substrate affinities and direction of growth with respect to current in Holopus mikihe (see Appendix 1 for species authorities) and Holopus rangii. However, due to their cryptic habitat, there has been little other research on the ecology of these organisms, and most aspects of life history in extant cyrtocrinids remain largely unknown.

Growth Rates and Regeneration Frequencies in other Crinoid Taxa.Directly measured growth rates of several non-comatulid crinoid species have been used to estimate individuals' ages (Table 1). The methods used by Duco and Roux (1981) and Messing et al. (2007) yielded only a lower bound on the age of the oldest individuals, the former being based on the oldest single individual in the population and the latter on the stalk growth rate; other authors (e.g., Oji 1989, Roux 1976) estimated a mean age for populations based on measurements of the whole population, as is done in the research presented here.

Observations of autotomy behavior in the isocrinid Metacrinus rotundus from Japan indicate that they are fairly robust to mechanical stress: grasping the arm with forceps neither breaks arms nor induces autotomy (Oji and Okamoto 1994). It is therefore generally assumed that regenerating arms in fully-developed individuals indicate nonlethal interactions with predators and can be used to estimate predator encounter rates (Baumiller 2013a). Thus, if rates of regrowth are known, the frequency of nonlethal arm loss can be used to estimate the frequency of interaction with predators. In general, fewer injured individuals are seen in fossil assemblages than in living ones (Table 2). This is due to some combination of taphonomic effects, in which postmortem breakage tends to obscure the visibility of nonlethal injury, and genuinely higher frequencies of predation in present-day marine ecosystems than in similar environments in the geologic past. The magnitude of the former effect is usually on the order of 1\% difference (Syverson 2014), whereas the latter is much more significant.

Specimens of the isocrinid Endoxocrinus from the tropical western Atlantic show a significantly increased frequency of regenerating arms in shallower water. Individuals collected in depths $>500 \mathrm{~m}(n=75)$ had an average of $25 \%$ of their arms injured and regenerating, while those from $>500 \mathrm{~m}$ depth $(n=79)$ had around $13 \%$ of arms injured (Oji 1996). The eastern Pacific ten-armed feather star, Florometra serratissima, also shows higher arm regeneration frequency in shallower water. In a sample from $79 \mathrm{~m}$, an average of $18 \%$ of the arms of individuals were regenerating, compared to $4 \%$ at $208 \mathrm{~m}$ and $1 \%$ at $1143 \mathrm{~m}$ (Baumiller 2013b). 
Table 2. Comparisons of injury frequency among different crinoids and other echinoderms.

\begin{tabular}{|c|c|c|c|c|c|}
\hline Taxon & Time & $\begin{array}{c}\text { Individuals } \\
\text { injured }\end{array}$ & $\begin{array}{l}\text { Arms } \\
\text { injured }\end{array}$ & Frequency (d) & Reference \\
\hline Endoxocrinus spp. & Modern & $71 \%$ & $16 \%-61 \%$ & & Oji 1996 \\
\hline Florometra serratissima & Modern & $18 \%$ & $1 \%-18 \%$ & $650-850$ & Baumiller 2013a,b \\
\hline Cenometra bella & Modern & $100 \%$ & $29 \%$ & $8-12$ & Baumiller and Gahn 2013 \\
\hline Pilocrinus moussoni & Jurassic & $8.3 \%$ \# & & & Hess 2014 \\
\hline Rhodocrinites kirbyi & Mississippian & $26 \%$ & $8 \%$ & $30-42$ & Baumiller and Gahn 2013 \\
\hline Le Grand crinoid fauna & Mississippian & $9 \%$ & & & Gahn and Baumiller 2005 \\
\hline Paleozoic crinoids & $\begin{array}{l}\text { Devonian- } \\
\text { Pennsylvanian }\end{array}$ & $12 \%$ & & & Baumiller and Gahn 2004 \\
\hline
\end{tabular}

*Value is approximate.

\# Cup only.

The only cyrtocrinids in which injury has been observed are the fossil species Eugeniacrinites cariophilites and Pilocrinus moussoni from the Late Jurassic. Three of 36 cups (8.3\%) had visible bite marks in P. moussoni, and "nearly 10\%" of 470 cups of $E$. cariophilites were "mutilated", a term which here includes swelling and atrophy, as well as injury; some, however, had visible bite marks (Hess 2014).

Although injury and regeneration are known from collected Holopus specimens [one specimen dissected by Donovan (1992) had a regrowing arm, and one pictured in Donovan and Pawson (2008) is visibly injured], no attempt has been made to estimate injury and regeneration frequency in Holopus. Here, we provide the first estimates of growth rates, lifespan, and injury frequency in $H$. mikihe based on in situ observations of a living population.

\section{Methods}

Location of Dives.-Data were collected in June 2012, July 2013, and May 2014. Video, still photographs, and several specimens were collected from the submersible IDABEL at approximately $16^{\circ} 18^{\prime} \mathrm{N} 86^{\circ} 36^{\prime} \mathrm{W}$ off the coast of Roatán, Honduras, at depths between 430 and $640 \mathrm{~m}$.

Holopus mikihe was observed on vertical and overhanging surfaces of boulders. Other crinoids collected or observed in the same area are listed in Table 3. Other hard-substrate organisms included a variety of hexactinellid sponges (e.g., Farrea), demosponges (e.g., Desmacellidae, Petrosiidae, Geodiidae, Spongosorites sp., Corallistes sp.), asteroschematid and other ophiuroids, echinoids (e.g., Calocidaris micans, Plesiodiadema antillarum), asteroids (e.g., Novodinia antillensis), scleractinian corals (e.g., Dendrophyllia alternata and numerous solitaries), antipatharians, octocorals (e.g., Primnoidae, Plexauridae, Ellisellidae), sea anemones, stylasterid hydroids, serpulid polychaetes, and various decapod crustaceans (e.g., Homola sp., Chyrostylidae). Relatively few bottom-associated fishes were observed, e.g., Synagrops bellus (Acropomatidae), Chaunax pictus (Chaunacidae), Ijimaia antillarum (Ateleopodidae), Grammicolepis brachiusculus (Grammicolepididae), Beryx decadactylus (Berycidae), Oxynotus caribbaeus (Oxynotidae), and Bythitidae. 
Table 3. Crinoid species identified in submersible trips off Roatán, Honduras, between 2012 and 2014.

\begin{tabular}{ll}
\hline Order/family & Species/subspecies \\
\hline Isocrinida & Cenocrinus asterius \\
Isselicrinidae & Endoxocrinus parrae carolinae \\
Isselicrinidae & \\
Comatulida & Comactinia meridionalis hartlaubi \\
Comatulidae (formerly Comasteridae) & Davidaster discoideus \\
Comatulidae & Neocomatella pulchella \\
Comatulidae & Crinometra brevipinna \\
Charitometridae & Democrinus sp. \\
Bourgueticrinidae & Unidentified genus and species \\
Atelecrinidae & \\
Cyrtocrinida & Holopus mikihe \\
Holopodidae & Cyathidium pourtalesi \\
Holopodidae &
\end{tabular}

Data Collection.-The submersible was equipped with a pair of parallel scaling lasers $10 \mathrm{~cm}$ apart. Specimen size was measured at the widest point of the calyx by importing the photograph or video frame into Adobe Illustrator ${ }^{\circ}$, taking measurements by drawing vector lengths, and comparing calyx diameter measurements (Fig. $2 \mathrm{~A}$ ) to the 10-cm scale bar formed by the lasers (Fig. 2B). The photographs and videos were taken at variable distance from the rock face, such that image scale varies from 0.22 to $5.12 \mathrm{~m}$ in the horizontal dimension. In total, 817 measurements were taken over the 3 yrs combined: 273 from 2012, 344 from 2013, and 200 from 2014.

Sixty individuals were observed more than once over the 3 yrs of sampling. Growth rates were estimated by year-to-year changes in measurements of these individuals. Our ability to revisit sites was facilitated by two factors: the excellent knowledge of the localities by one of the authors (KS), whose experience includes piloting more than 1200 dives in the submersible at Halfmoon Bay, Roatan, since 1998, and the fact that the topography in these sites is highly irregular with many landmarks. Thus, while finding particular boulders with Holopus populations proved relatively easy, identifying specific individuals year after year required referring to close-up images from previous years while maneuvering the submersible. One individual with two arms completely missing in 2012 (Fig. 2C) was photographed in all 3 yrs; its visceral mass was apparently uninjured, allowing an estimate of arm regeneration rate alone. No new individuals appeared, and no individuals disappeared, at the revisited sites over the period of observation; therefore, no life table could be formulated.

In each image measured, the number of visibly injured specimens was noted, along with the number with arms fully opened and the number in good close-up focus. To estimate the mean time between injuries, we followed the method of Baumiller (2013a). Total image area was calculated for each image, again using the 10-cm laser scale bar, which allowed computation of population density per image. All calculations were carried out in R (R Core Team 2014). 

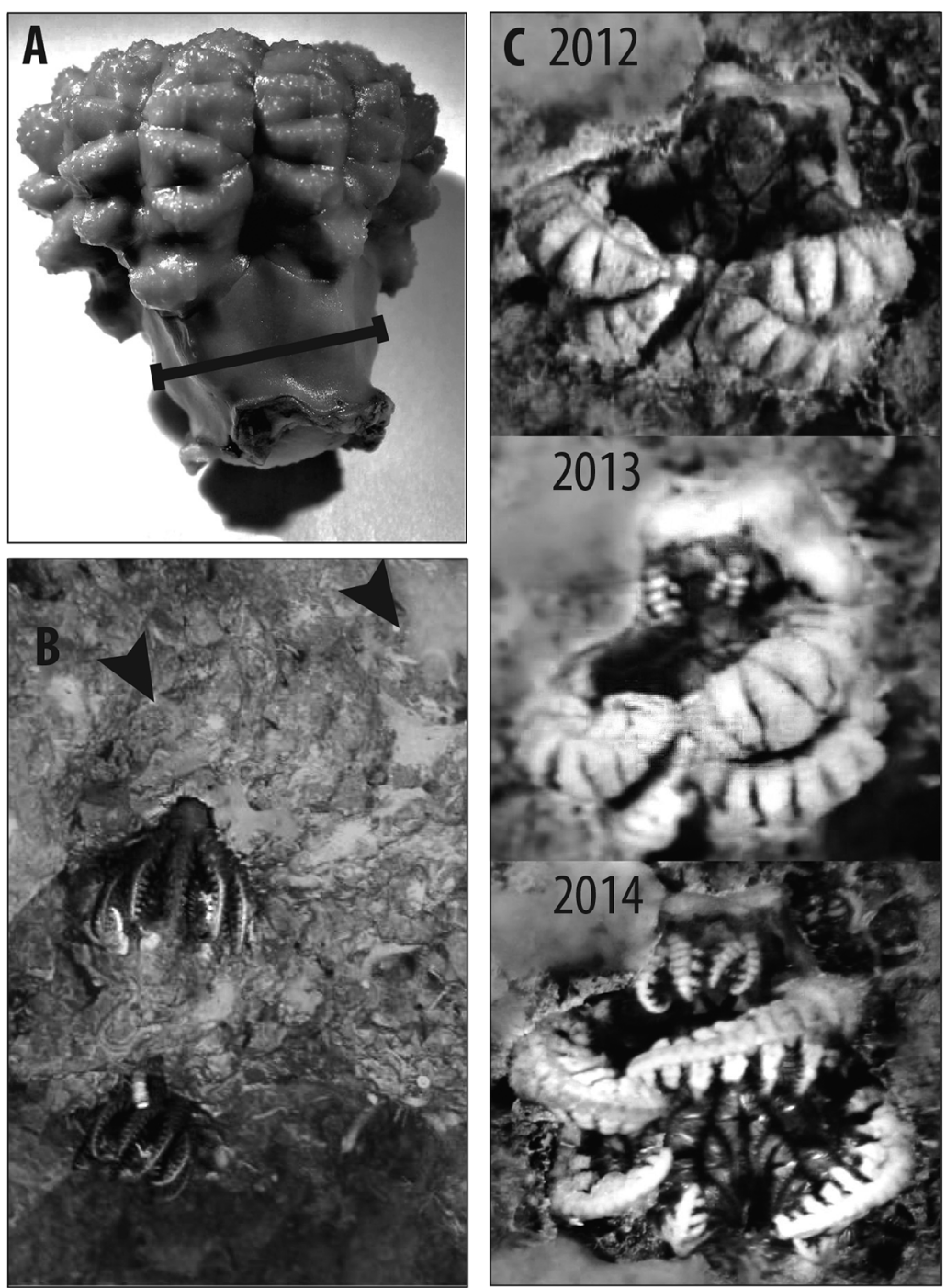

Figure 2. (A) Measurement of Holopus calyx size at widest point of calyx, demonstrated on a dead preserved individual. (B) Example of parallel lasers (white dots) used for size measurement of living specimens. (C) Individual with regrowing arms used in the calculation of arm regrowth rate and photographed in all 3 yrs. Note complete absence of radials in 2012.

\section{RESULTS}

Size and Spatial Distribution.-The sizes of the measured $H$. mikihe specimens followed a bimodal size distribution. Kernel density estimation, conducted using the R base function "density", estimated the values of these modes at about 0.84 $\mathrm{cm}$ and $1.79 \mathrm{~cm}$ (Fig. 3A). These size modes corresponded to two visually apparent life stages: the button-shaped "juveniles" (Fig. 3B, left), in which the calyx did not elevate the crown above the surface, but formed a flattened hemisphere attached to 

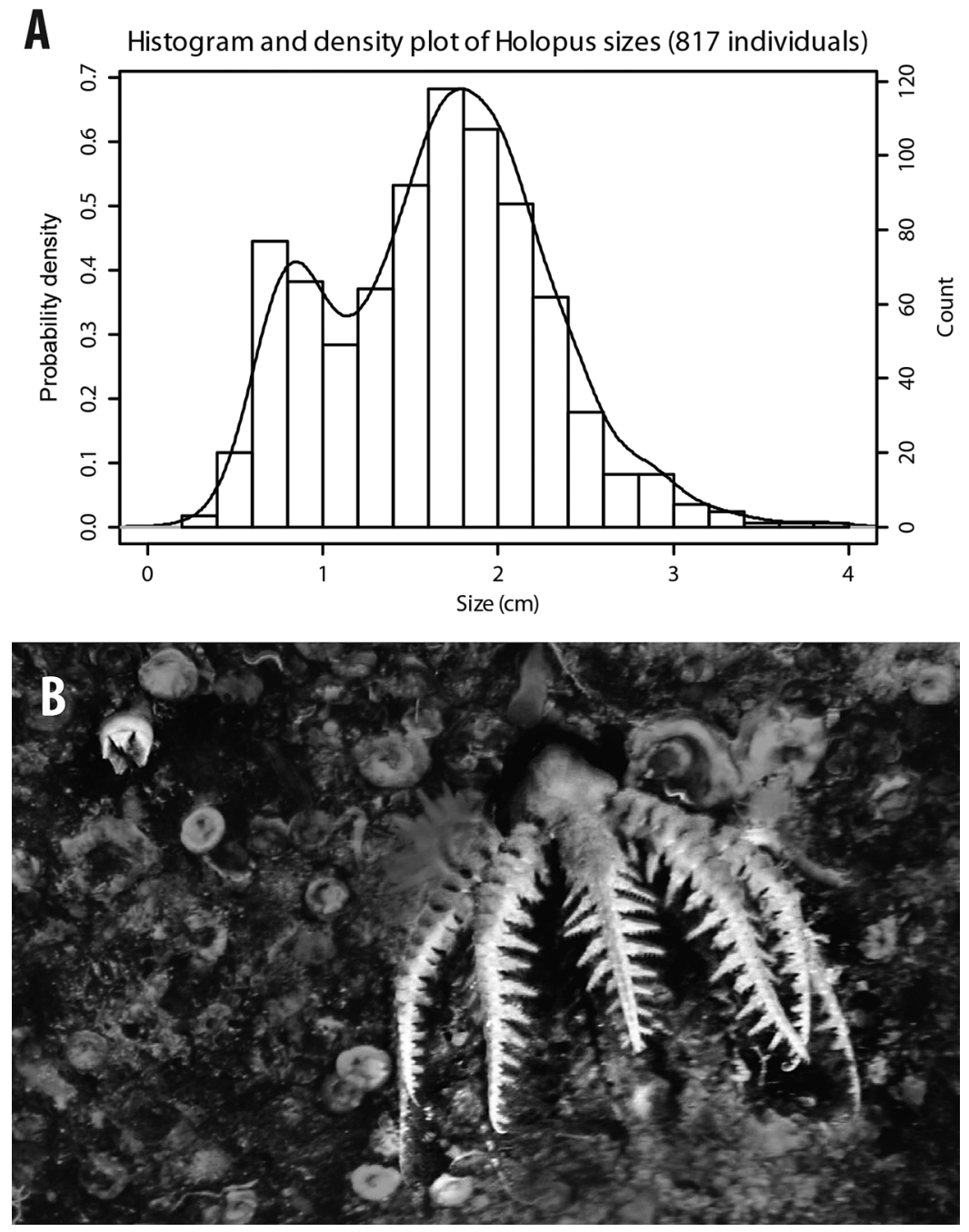

Figure 3. (A) Size histogram and probability density curve (calculated by kernel density estimation) for all 817 individuals, showing bimodal size distribution. Based on the density curve, "juvenile" size mode is at $0.84 \mathrm{~cm}$, "adult" at $1.79 \mathrm{~cm}$, and the minimum between them is $1.14 \mathrm{~cm}$. (B) Example "juvenile" (top left) and "adult" individuals of Holopus mikihe, along with a large Cyathidium (dark with coiled arms) at upper right. White rings on substrate are bases of dead individuals, usually of indeterminate genus. Note similarity of calyx shape in juvenile Holopus and adult Cyathidium.

the rock, and the fist-shaped "adults" (Fig. 3B, right), in which the calyx was taller than it was wide, and crown height reached a few centimeters above the surface. The minimum between the two modes was at about $1.14 \mathrm{~cm}$, which was used as the dividing line between adult and juvenile specimens for the remainder of the data analysis.

The total area of an image was negatively correlated with the population density at a rate of -0.041 individuals $\mathrm{m}^{-2}$ per square meter of image $\left(R^{2}=0.034, P=0.0038\right)$; that is, closer-range images were likely to appear more densely populated. This was probably because the smallest individuals were not visible in the largest-scale images. 
Table 4. Age estimates for Holopus mikihe individuals of 1st, 50th, and 99th percentile sizes, based on 50th and 99th percentile growth rates.

\begin{tabular}{lccc}
\hline & & \multicolumn{2}{c}{ Age $(\mathrm{yrs})$, by growth rate percentile } \\
\cline { 3 - 4 } Percentile & Size $(\mathrm{cm})$ & 50 th $\left(0.044 \mathrm{~cm} \mathrm{yr}^{-1}\right)$ & 99th $\left(0.194 \mathrm{~cm} \mathrm{yr}^{-1}\right)$ \\
\hline 1st (smallest) & 0.52 & 12.0 & 2.7 \\
50th (median) & 1.70 & 38.9 & 8.7 \\
99th (largest) & 3.12 & 71.5 & 16.1 \\
\hline
\end{tabular}

Growth And Regeneration Rates.-The 50th and 99th percentile growth rates among the sample of 60 specimens (or individuals) over the 3 yrs sampled were, respectively, $0.044 \mathrm{~cm} \mathrm{yr}^{-1}$ and $0.194 \mathrm{~cm} \mathrm{yr}^{-1}$. The age estimates for very small, median, and very large specimens (1st, 50th, and 99th percentiles of size) in the sample of 817 measured individuals are given in Table 4. As the errors resulting from this method of measurement are large relative to the growth rates, the left tail of the growth rate distribution is below 0 , and so no minimum age estimates are given.

When growth rates among the repeatedly-sampled specimens are split by size class, using the value of $1.14 \mathrm{~cm}$ derived above from the larger set of body sizes and the mean size and growth rate of each individual over all years sampled, growth rates of juvenile and adult size classes differ significantly: adults grow faster than juveniles by a factor of about 2.5 [individuals $\leq 1.14 \mathrm{~cm}$ : mean $=0.026($ SD 0.069$) \mathrm{cm}$ $\mathrm{yr}^{-1}$; individuals $>1.14 \mathrm{~cm}$ : mean $=0.063(\mathrm{SD} 0.045) \mathrm{cm} \mathrm{yr}^{-1}, \sigma^{2}=0.045$; unpaired $t$-test: $t=-2.419, P=0.019]$. If we take this slower juvenile mean growth rate at face value, we find that an individual would be approximately 44 yrs old when it reached 1.14 $\mathrm{cm}$. The modal $1.79-\mathrm{cm}$ adult in our sample, after a further $0.65 \mathrm{~cm}$ of growth the adult rate, would then be approximately 59 yrs old. However, the large variance in the juvenile growth rate suggests that it is near the lower boundary of detection by this method, and is probably not a reliable estimate.

Since the median adult in our sample is approximately 50 yrs old, if the population size is stable, then it would take 50 yrs for complete population turnover, corresponding to a death rate of $100 \%$ in $50 \mathrm{yrs}\left(=2 \% \mathrm{yr}^{-1}\right)$. Therefore, we would expect to observe three or four deaths among our sample population of 60 during the $693 \mathrm{~d}$ separating the first and last observations. Dead Holopus are recognizable as empty calyx stumps, which are common and even abundant in some images. However, no individuals died or disappeared completely during this time period; the odds of this occurring with uniform $2 \%$ per year mortality risk are about 1 in 10 , which means that the death rate was lower than expected given the age distribution. Similar reasoning applies to the lack of new individuals-although very young specimens may be unrecognizable in the images, we would expect some three or four individuals to pass into the visible size range and thus appear to be "born" during the approximate 2-yr observation period, but we observed no such instances.

The rate of arm regeneration in the single individual in which it was measured was, on average, $0.6 \mathrm{~cm} \mathrm{yr}^{-1}$ (i.e., $0.00167 \mathrm{~cm} \mathrm{~d}^{-1}$ ); this was about 10 times the median growth rate and four times the 95th percentile growth rate.

Of all measured adults, $9.8 \%$ had visible injuries, an underestimate of the total injury frequency, as many were photographed with arms closed, obscuring any injuries to the distal arms (see Fig. 4). Of the $54 \%$ that were photographed fully open with all arms visible, $18 \%$ exhibited visible injury. Also, large-scale images often did not 


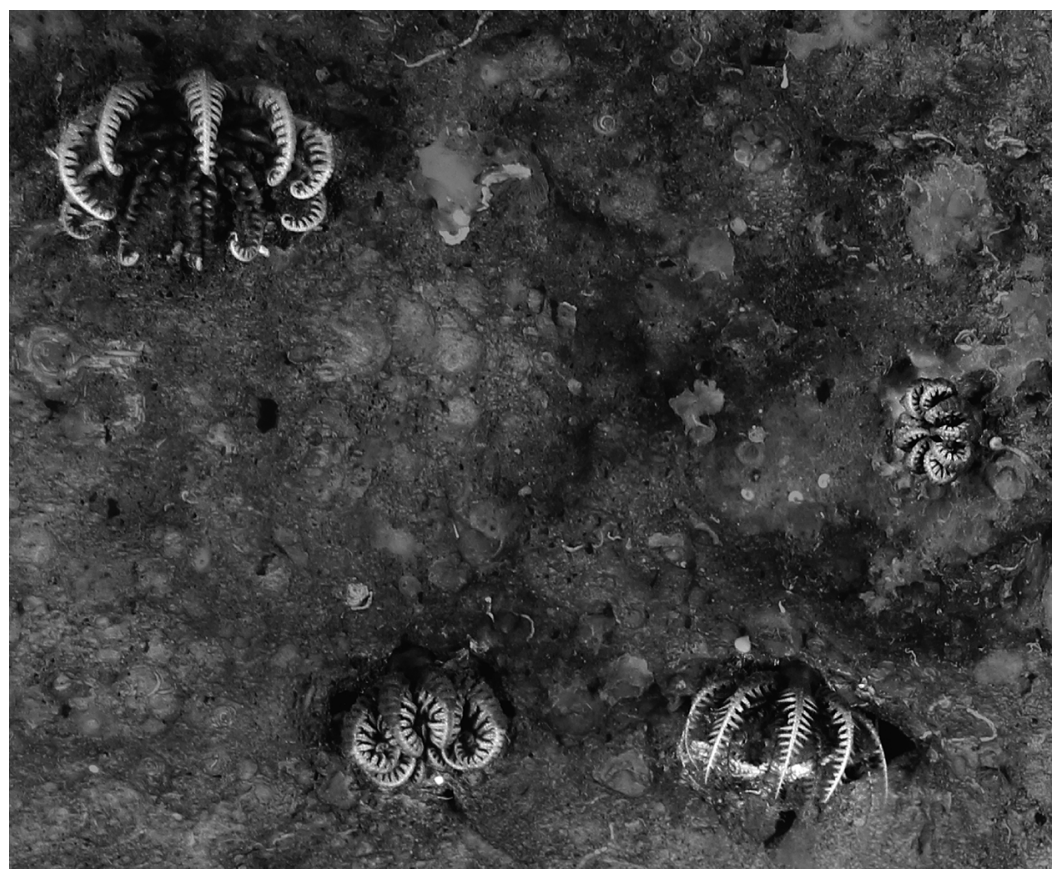

Figure 4. Different arm positions in adult Holopus mikihe: fully open (bottom right), mostly open with distal arm tips curled (top left), partially closed (bottom left), almost completely closed (right center). See Figure 1A for an example of the fully closed position (in a dead individual). These partially-closed postures would protect the distal arm tips and permit relatively quick movement to a fully closed position, while still allowing some food collection.

provide enough detail to identify injury. Accordingly, we used $9.8 \%$ as a minimum estimate of adult Holopus injury frequency. We observed no arm injuries in juveniles; either injury to such small specimens is rare, or most arms were either in unobservable positions or were too small and unresolved in images.

The average arm length in adults was approximately $4 \mathrm{~cm}$. We assumed that injuries are evenly distributed over the length of the arm; that is, on average half the arm is lost. Then, following the equation in Baumiller $(2013 \mathrm{a}), t_{\mathrm{r}}=(2 \mathrm{~cm}) /(0.00167$ $\left.\mathrm{cm} \mathrm{d}^{-1}\right)$ and $P_{\text {ind }}=0.098$, so $T=\left(-t_{\mathrm{r}} \ln \left(P_{\text {ind }}\right)\right)^{-1}=\left(0.00193 \pm 0.00007 \mathrm{~d}^{-1}\right)^{-1}=517 \pm 18$ $\mathrm{d}$ between injuries. Given the locations of specimens on vertical and overhanging rock faces protected from falling rock debris, we speculate that all arm injuries are predation-related.

\section{Discussion}

Growth And Life History.-The age of the average specimen of $H$. mikihe is probably comparable to, or greater than, that of other deep-water stalked crinoids (Table 1). Using a constant growth rate, the 99th percentile growth rate gives the median individual's age at $8.7 \mathrm{yrs}$, which is lower than that estimated for either $M$. rotundus or Endoxocrinus spp. However, the 50th percentile growth rate gives a median age of $39 \mathrm{yrs}$, which is substantially older than the age estimates for any of the species in Table 1. Additionally, these ages do not take into account the different growth rates in adults and juveniles. Regardless of the actual magnitude of the 
difference between the juvenile and adult growth rates, the slower juvenile growth rate means that these ages for $H$. mikihe are underestimates.

Almost all extant crinoids develop a stalk following a planktonic or brooded larval stage. The feather stars, the majority of order Comatulida, pass through a stalked postlarval stage before taking up a free existence. Taxa that retain a stalk throughout life (e.g., Isocrinida, Hyocrinida, Bourgueticrinidae) do not exhibit a well-defined postlarval stage. Among extant Cyrtocrinida, only members of Holopodidae (Holopus and Cyathidium) lack a stalk at any known developmental stage, although larvae, which exhibit an internally-developing stalk in other crinoid taxa, have not yet been observed in Holopodidae. In this case, juveniles of $H$. mikihe are morphologically similar to adults of Cyathidium spp., which is consistent with the general assessment of Cyathidium as a paedomorphic relative to Holopus, although Améziane-Cominardi (1999) notes that tegminal characters of Cyathidium are peramorphic. Roux (1976) estimated that the isocrinid Endoxocrinus wyvillethompsoni passed through a 2.5-yr postlarval juvenile period, based on growth rates from a large Antarctic comatulid. However, the very slow growth rate documented here for $H$. mikihe indicates that the juvenile period may be much longer, possibly lasting decades.

The observed arm regeneration rate of $0.6 \mathrm{~cm} \mathrm{yr}^{-1}$ is much slower than the extrapolated annual rate of $4.4-4.8 \mathrm{~cm} \mathrm{yr}^{-1}$ estimated for a specimen of the isocrinid Neocrinus decorus at similar depths in The Bahamas (Messing et al. 2007) or the initial rate of $6.2 \mathrm{~cm} \mathrm{yr}^{-1}$ recorded for aquarium-raised isocrinids, $M$. rotundus, that had autotomized their entire crown (Amemiya and Oji 1992). However, since the arms of $H$. mikihe are much more robust than those of either isocrinid, the volumetric rate of stereom addition may be more similar.

Crinoids appear to experience predator-related injuries less often in deep water than in shallow water (Oji 1996, Baumiller 2013a). Given the escalating pace of predator-prey relations that has been observed between the Mesozoic and the present by numerous authors (see Vermeij 2013), this is consistent with the pattern of migration from onshore to offshore environments over the history of the less-motile clades of modern crinoids (Bottjer and Jablonski 1988, Baumiller et al. 2010). As a result, deepwater assemblages are often "archaic" in appearance, low in modern durophagous predators and dominated by sessile epifaunal suspension feeders (Aronson 1991, Améziane and Roux 1997). The comparatively low injury rates (Table 2) found here for $H$. mikihe are consistent with their low-energy, deep-water community. The injury rates are lower even than those of some shallow-water Paleozoic crinoid populations (Gahn and Baumiller 2005). Assuming that most mortality in adults is caused by predatory interactions, an average adult age of 50 yrs means an average "waiting time" of 50 yrs for a lethal predatory encounter. Since our injury calculation above gave a waiting time of about $1.4 \mathrm{yrs}$, if injury frequency is independent of size among adult individuals, this means that about 3\% of interactions between $H$. mikihe and its predators are fatal. Injury and fatality frequencies this low suggest that $H$. mikihe is not a major prey item for any predator in this locality.

The lack of new individuals during the observation period, in combination with the decreased size heterogeneity within more densely populated regions, suggests that recruitment occurs in local bursts either very rarely and/or sporadically. The pattern of juveniles growing more slowly than adults is known from other organisms. Trees in dense forests, for example, will remain sapling-sized for many years while waiting for a canopy opening, a pattern described as "advance regeneration" (Messier 
et al. 1999). This is consistent with the very slow and temporally uneven death rate observed. However, in the focal system there is no known resource whose role is obviously comparable to that of sunlight in a forest canopy, as the Holopus populations do not appear dense enough to restrict access to current-borne food particles, and individuals living in regions of high population density did not have significantly stunted growth. Alternatively, growth rate may be governed purely by current velocity, which regulates food availability. Near the rock surface, currents are slowed by boundary effects; if juveniles are confined within this slow-flowing boundary layer, their food supply may thus simply be insufficient to allow rapid growth until the transition to their adult calyx shape elevates them into more turbulent water. In this case, a rapid change from slower to faster growth could produce the observed local minimum in size frequency around the size where the growth speed transition occurs. It is also likely that different rates or causes of mortality apply to the juvenile and adult size classes; higher mortality in juveniles than in adults would accentuate the size frequency minimum between the two stages.

HABITAT AND BEHAVIOR.-We observed no consistent current direction at crinoid sites during submersible dives; the trajectories of particles of marine snow indicated that the water moved slowly and changed direction frequently, although we observed apparently tidally-induced or influenced flow of up to approximately $50 \mathrm{~cm} \mathrm{~s}^{-1}$ and parallel to the local slope in other areas. Therefore, we observed no clear orientation of the oral disc, funnel, bivium, or trivium with respect to the current; instead, the arm funnels of all individuals were oriented normal to the rock face. While this is contrary to preliminary observations published elsewhere, it is not inconsistent with the proposition that unidirectional current flow produces asymmetries (Grimmer and Holland 1990).

It has also been proposed that Holopus is a raptorial feeder, capable of contracting its arms very quickly to form a "cage" for large prey items (Grimmer and Holland 1990). However, the individuals observed closing their arms all appeared to be responding to water movements generated by the approaching submersible (and not, apparently, to the submersible's lights), and did so too slowly to capture actively motile organisms. Thus, we speculate that such arm closing is a defensive response. Moreover, the individuals observed with semi-closed arms did not appear to be in a cage-like position; instead, the center of the calyx's oral surface was exposed and the arms were distally enrolled (Fig. 4). Anatomical comparisons to other raptoriallyfeeding echinoderms, specifically the gorgonocephalid basket stars Gorgonocephalus caputmedusae (Emson et al. 1991, Rosenberg et al. 2005) and Astrophyton muricatum (Macurda 1976), are consistent with these inferences: no food-capturing hooks or similar articulated adambulacral structures have ever been described for any holopodid (Donovan 1992). On this basis, we found no evidence in favor of the raptorial-feeding hypothesis.

\section{ACKNOWLEDGMENTS}

Funding was provided under NSF grants 1036219 (CGM) and 10366393 (TKB)Collaborative Research: Assembling the Echinoderm Tree of Life, by a Nova Southeastern University President's Faculty Research and Development Award (CGM), and by National Geographic Society Grant CRE Research Grant 9283-13 (TKB). The authors thank P Etnoyer for loan of lasers and DY Poon for comments regarding advance regeneration in forest trees. 


\section{Literature Cited}

Amemiya S, Oji T. 1992. Regeneration in sea lilies. Nature. 357:546-547. http://dx.doi. org/10.1038/357546a0

Améziane N, Roux M. 1997. Biodiversity and historical biogeography of stalked crinoids (Echinodermata) in the deep sea. Biodivers Conserv. 6:1557-1570. http://dx.doi. org/10.1023/A:1018370620870

Améziane N. 1999. Les genres Cyathidium et Holopus au sein des Cyrtocrinida (Crinoidea; Echinodermata). J Nat Hist. 33.

Améziane-Cominardi N, Bourseau, Jean-Paul, Avocat R, Roux M. 1990. Les crinoïdes pédonculés de Nouvelle Calédonie: inventaire et réflexions sur les taxons archaïques. In: Jangoux M, De Ridder C, Dubois P, Lahaye M-C, editors. Echinoderm research. Rotterdam: Balkema. p. 117-124.

Aronson RB. 1991. Predation, physical disturbance, and sublethal arm damage in ophiuroids: a Jurassic-Recent comparison. Mar Ecol Press Ser. 74:91-97. http://dx.doi.org/10.3354/ meps074091

Baumiller TK. 2013a. Ephemeral injuries, regeneration frequencies, and intensity of the injuryproducing process. Mar Biol. 160:3233-3239. http://dx.doi.org/10.1007/s00227-013-2302-9

Baumiller TK. 2013b. Arm regeneration frequencies in Florometra serratissima (Crinoidea, Echinodermata): impact of depth of habitat on rates of arm loss. Cah Biol Mar. 54:571 - 576.

Baumiller TK, Gahn FJ. 2004. Testing predator-driven evolution with Paleozoic crinoid arm regeneration. Science. 305:1453-1455. http://dx.doi.org/10.1126/science.1101009

Baumiller TK, Gahn F). 2013. Reconstructing predation pressure on crinolds: estimating arm-loss rates from regenerating arms. Paleobiology. 39:40-51. http://dx.doi. org/10.1666/0094-8373-39.1.40

Baumiller TK, Gaździcki A. 1996. New crinoids from the Eocene La Meseta Formation of Seymour Island, Antarctic Peninsula. In: Gaździcki A, editor. Palaeontological results of the Polish Antarctic Expedition. Vol. II. Paleontologica Polonica. p. 101-116.

Baumiller TK, Salamon MA, Gorzelak P, Mooi R, Messing CG, Gahn FJ. 2010. Post-Paleozoic crinoid radiation in response to benthic predation preceded the Mesozoic marine revolution. Proc Natl Acad Sci. 107:5893-5896. http://dx.doi.org/10.1073/pnas.0914199107

Bottjer DJ, Jablonski D. 1988. Paleoenvironmental patterns in the evolution of post-Paleozoic benthic marine invertebrates. Palaios. 3:540. http://dx.doi.org/10.2307/3514444

Carpenter PH. 1884. Report upon the Crinoidea collected during the voyage of H.M.S. Challenger during the years 1873-76. Part I: General morphology, with descriptions of the stalked crinoids. Smithsonian Institution. http://dx.doi.org/10.5962/bhl.title.11805

Charbonnier S, Vannier J, Gaillard C, Bourseau J-P, Hantzpergue P. 2007. The La Voulte Lagerstätte (Callovian): evidence for a deep water setting from sponge and crinoid communities. Palaeogeogr Palaeoclimatol Palaeoecol. 250:216-236. http://dx.doi.org/10.1016/j. palaeo.2007.03.013

Donovan SK. 1992. Scanning EM study of the living cyrtocrinid Holopus rangii (Echinodermata, Crinoidea) and implications for its functional morphology. J Paleontol. 66:665-675.

Donovan S, Jakobsen S. 2004. An unusual crinoid-barnacle association in the type area of the Danian (Paleocene), Denmark. Lethaia. 37:407-415. http://dx.doi. org/10.1080/00241160410002126

Donovan SK, Pawson DL. 2008. A new species of the sessile crinoid Holopus d'Orbigny from the tropical western Atlantic, with comments on holopodid ecology (Echinodermata: Crinoidea: Holopodidae). Zootaxa. 1717:31-38.

Duco A, Roux M. 1981. Modalités particulières de croissance liées au milieu abyssal chez les Bathycrinidae (Echinodermes, Crinoïdes pédonculés). Oceanol Acta. 4:389-394.

Emson RH, Mladenov PV, Barrow K. 1991. The feeding mechanism of the basket star Gorgonocephalus arcticus. Can J Zool. 69:449-455. 
Gahn FJ, Baumiller TK. 2005. Arm regeneration in Mississippian crinoids: evidence of intense predation pressure in the Paleozoic? Paleobiology. 31:151-164. http://dx.doi. org/10.1666/0094-8373(2005)031<0151:ARIMCE >2.0.CO;2

Grimmer JC, Holland ND. 1990. The structure of a sessile, stalkless Crinoid (Holopus rangii). Acta Zool. 71:61-67. http://dx.doi.org/10.1111/j.1463-6395.1990.tb01070.x

Heinzeller T, Fechter H. 1995. Microscopical anatomy of the Cyrtocrinid Cyathidium meteorensis (sive foresti) (Echinodermata, Crinoidea). Acta Zool. 76:25-34. http://dx.doi. org/10.1111/j.1463-6395.1995.tb00979.x

Hess H. 2014. The crinoid Eugeniacrinites cariophilites from the Late Jurassic of southern Germany: babies, cripples and enigmatic wing plates. Swiss J Palaeontol. 133.

Hess H, Messing CG, Ausich WI. 2011. Part T. Echinodermata 2: Crinoidea 3. Revised. Lawrence, Kansas: University of Kansas Paleontological Institute.

Lindsay SM. 2010. Frequency of injury and the ecology of regeneration in marine benthic invertebrates. Integr Comp Biol. 50:479-493. http://dx.doi.org/10.1093/icb/icq099

Macurda DB. 1976. Skeletal modifications related to food capture and feeding behavior of the basketstar Astrophyton. Paleobiology. 2:1-7.

Messier C, Doucet R, Ruel J-C, Claveau Y, Kelly C, Lechowicz MJ. 1999. Functional ecology of advance regeneration in relation to light in boreal forests. Can J For Res. 29:812-823. http:// dx.doi.org/10.1139/x99-070

Messing CG, David J, Roux M, Améziane N, Baumiller TK. 2007. In situ stalk growth rates in tropical western Atlantic sea lilies (Echinodermata: Crinoidea). J Exp Mar Biol Ecol. 353:211-220. http://dx.doi.org/10.1016/j.jembe.2007.08.021

Mladenov PV. 1983. Rate of arm regeneration and potential causes of arm loss in the feather star Florometra serratissima (Echinodermata: Crinoidea). Can J Zool. 61:2873-2879. http://dx.doi.org/10.1139/z83-375

Oji T. 1989. Growth rate of stalk of Metacrinus rotundus (Echinodermata: Crinoidea) and its functional significance. J Fac Sci Univ Tokyo. 22:39-51.

Oji T. 1996. Is predation intensity reduced with increasing depth? Evidence from the West Atlantic stalked crinoid Endoxocrinus parrae (Gervais) and implications for the Mesozoic Marine Revolution. Paleobiology. 22:339-351.

Oji T, Okamoto T. 1994. Arm autotomy and arm branching pattern as anti-predatory adaptations in stalked and stalkless crinoids. Paleobiology. 20:27-39.

R Core Team. 2014. R: a language and environment for statistical computing. 3.1.1 ed. Vienna, Austria: R Foundation for Statistical Computing.

Rosenberg R, Dupont S, Lundälv T, Sköld HN, Norkko A, Roth J, Stach T, Thorndyke M. 2005. Biology of the basket star Gorgonocephalus caputmedusae (L.). Mar Biol. 148:43-50. http:// dx.doi.org/10.1007/s00227-005-0032-3

Rouse GW, Jermiin LS, Wilson NG, Eeckhaut I, Lanterbecq D, Oji T, Young CM, Browning T, Cisternas P, Helgen LE, et al. 2013. Fixed, free, and fixed: the fickle phylogeny of extant Crinoidea (Echinodermata) and their Permian-Triassic origin. Mol Phylogenet Evol. 66:161-181. http://dx.doi.org/10.1016/j.ympev.2012.09.018

Roux M. 1976. Aspects de la variabilité et de la croissance au sein d'une population de la pentacrine actuelle: Annacrinus wyvillethomsoni Jeffreys (Crinoidea). Thallas Jugosl. 12:307-320.

Salamon MA, Gorzelak P. 2011. A new spoon-like crinoid (Hemicrinus, Cyrtocrinida) from the Danian (Palaeogene) of Poland and overview of Cretaceous hemicrinids. Paleontol Res. 15:23-30. http://dx.doi.org/10.2517/1342-8144-15.1.023

Salamon MA, Gorzelak P, Zaton M. 2009. In quest of cyrtocrinid origins: evidence from Late Triassic ossicles from the Tatra Mountains. Acta Palaeontol Pol. 54:171-174. http://dx.doi. org/10.4202/app.2009.0119

Syverson VJ. 2014. Predation, resistance, and escalation in sessile crinoids. PhD dissertation. Ann Arbor: University of Michigan. 
Vermeij GJ. 1993. Evolution and escalation : an ecological history of life. Princeton: Princeton Univ Press.

Vermeij GJ. 2013. On escalation. Annu Rev Earth Planet Sci. 41.

Wisshak M, Neumann C, Jakobsen J, Freiwald A. 2009. The "living-fossil community" of the cyrtocrinid Cyathidium foresti and the deep-sea oyster Neopycnodonte zibrowii (Azores Archipelago). Palaeogeogr Palaeoclimatol Palaeoecol. 271:77-83. http://dx.doi. org/10.1016/j.palaeo.2008.09.015

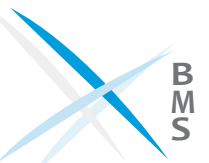


Appendix 1. Species and authorities mentioned in the present study.

Endoxocrinus (Annacrinus) wyvillethomsoni (Jeffreys, 1870)

Astrophyton muricatum (Lamarck, 1816)

Bathycrinus carpenterii (Danielsen and Koren, 1877)

Beryx decadactylus Cuvier, 1829

Calocidaris micans (Mortensen, 1903)

Cenocrinus asterius (Linnaeus, 1767)

Comactinia meridionalis hartlaubi Messing, 1978

Crinometra brevipinna (Pourtalès, 1868)

Cyathidium pourtalesi Améziane, 1999

Davidaster discoideus (Carpenter, 1888)

Dendrophyllia alternata Pourtalès, 1880

Endoxocrinus parrae carolinae (AH Clark, 1934)

Endoxocrinus wyvillethompsoni (Jeffreys, 1870)

Eugeniacrinites cariophilites (von Schlotheim, 1813)

Florometra serratissima Clark, 1907

Gorgonocephalus caputmedusae (Linnaeus, 1758)

Grammicolepis brachiusculus Poey, 1873

Holopus mikihe Donovan and Pawson, 2008

Holopus rangii d'Orbigny, 1837

Ijimaia antillarum Howell Rivero, 1935

Metacrinus rotundus Carpenter, 1884

Neocomatella pulchella (Pourtalès, 1878)

Neocrinus decorus Thomson, 1864

Novodinia antillensis (A. H. Clark, 1934)

Oxynotus caribbaeus Cervigón, 1961

Pilocrinus moussoni (Desor)

Plesiodiadema antillarum (A. Agassiz, 1880)

Synagrops bellus (Goode and Bean, 1896) 